\title{
Chapter 1 \\ Black Jacobins: Towards a Genealogy of a Transatlantic Trope
}

\author{
Raphael Hörmann
}

The trope of the Black Jacobins epitomizes transatlantic revolutionary crosscurrents and the close nexus of the fundamental transformations in the Atlantic world during the Age of Revolution. While the French Revolution precipitated slave revolts in the Caribbean, the revolutionary events in the Atlan- tic world, namely the Haitian Revolution, had decisive repercussions on the revolution in the metropole.' While the trope of the Black Jacobins has been prominent in the discourse on transatlantic revolutions ever since, its genealo- gy has rarely been explored; a lacuna that this essay seeks to address.

Trinidad-born Marxist C.L.R. James was the first to theorize these transatlantic interactions in the trope of the Black Jacobins in his ground-breaking history of the Haitian Revolution, The Black Jacobins: Toussaint Louverture and the San Domingo Revolution (1938/63). ${ }^{2}$ The trope has become almost synon- ymous with James' history, but his positions can be fruitfully contrasted with earlier uses of images depicting the Black Jacobins. Moreover, despite height- ened recent engagement with his eponymous history, James' contradictory uses of this trope have remained curiously underexplored. ${ }^{3}$ Thus, an exposi- tion of James' deployment of the Black Jacobin trope is absolutely essential here. In his study, James casts one of the major leaders of the Haitian Revo- lution, Toussaint Louverture, and, simultaneously, the slave masses as Black

1 Cf. David Barry Gaspar and David Patrick Geggus, A Turbulent Time: The French Revolution and the Greater Caribbean (Bloomington: Indiana University Press, 1997); Cf. David Patrick Geggus, ed., The Impact of the Haitian Revolution in the Atlantic World (Columbia, SC: Univ. of South Carolina Press, 2001).

2 C. L.R. James, The Black Jacobins: Toussaint Louverture and the San Domingo Revolution (2nd ed.) (London, etc.: Penguin, 2001).

3 For recent key works revisiting C.L.R. James' Black Jacobins, see David Scott, Conscripts of Modernity: The Tragedy of Colonial Enlightenment (Durham, NC: Duke University Press, 2005), Christian Høgsbjerg, C.L.R. James in Imperial Britain (Durham, NC, Duke University Press, 2014) and Christian Høgsbjerg \& Charles Forsdick, eds., The Black Jacobins Reader (Durham,NC, Duke University Press, 2017). 
Jacobins. As he insists, both were fueled by French radical revolutionary ideology, but adapted this Jacobin ideology to suit their own purposes in fighting (or leading) a slave revolution by diasporic Africans.

In spite of James' major achievements in theorizing the trope of the Black Jacobins, this figure is not James' invention. On the contrary, it dates back as far as the Haitian Revolution itself, as this essay will demonstrate. The key difference to James' emphatically positive, socio-revolutionary and racerevolutionary understanding of the Black Jacobins is that most Western contemporaries perceived these revolutionary qualities as transgressive, anarchistic and demonic. The Black Jacobins trope was intended to demonize the Haitian slave revolutionaries rather than extol their merits as fighters for emancipation. What for James became a trope of radical liberation entered history as a trope of horror.

This essay seeks to reconstruct the history of the transatlantic transformation of the trope of the Black Jacobins, from its connotations of horror to those of revolutionary emancipation. It avers that from the nineteenth century onwards, protagonists of the Black Atlantic, who belonged to a transnational and transatlantic network of often radical figures of the African diaspora, like James himself did later, played a key role in this reinterpretation.

\section{1 "It was gravely inaccurate in fact:" C. L. R. James' Black Jacobins and Misappropriation}

In what is not only the most famous but also one of the most sustained engagements with the trope of the Black Jacobins, James identifies the beginnings of the Haitian Revolution (1791-1804) as its birthplace. Forming "one of the great epics of revolutionary struggle and achievement, ${ }^{, 4}$ the Haitian Revolution marks the only successful slave revolution in modern history, and just as importantly, it also constitutes one of the first anti-colonial revolutions in the Americas: former slaves defeated Napoleon's troops and founded the "Black Republic" of Haiti in 1804. This "double revolution" overthrew slavery and colonialism in what had been the most profitable Caribbean colony. ${ }^{5}$ Moreover, as this essay will demonstrate, it spawned a transatlantic discourse that frequently equated slave revolution with lower-class social revolution.

4 Ibid., xviii.

5 Anthony Bouges, Empire of Liberty: Power, Desire, and Freedom (NH Hanover: Dartmouth Col- lege Press: University Press of New England, 2010), 114. 
James also stresses the dual character of the Haitian Revolution, not least since he considers the Haitian Revolution as an inspiration for future anticolonial revolutions in Africa. However, by placing the Black Jacobins trope at the heart of his narrativive, he risks adopting a Eurocentric perspective, since he regards French Revolutionary Enlightenment ideology as the major inspiration for the Haitian Revolution. The question of what triggered the Haitian Revolution has remained a moot point in scholarship. Some current studies have contested the orthodlox premise that the slave revolutionaries were influenced by French revolutionary thought. Instead, they identify African ideologies and vodun as potential triggers for the slave uprising. 6 For James, the slave revolutionaries from the African diaspora were inspired to revolt by the principlles of the French Revollution, while "[w]loodoo was the medium" of the initial revollution.7 Yet, this medium could carry a liberationist message independent of the Rights of Man. James acknowledges that voduris syncretic African ideology kindled the flames of revolution, as expressed in this mythical vodun chant: "We swear to destroy the whittes and all that they possess. Let us die rather, than fail to keep this vow. In another passage, he even seems to discount European Enlightenment ideology altogether, as he posits that the lived experience of the totalitarian torture regime of plantation slavery and the urge to overthrow it provided sufficient motivation for the slaves to start the revolution. As he asserts, "one does not need education or encouragement to cherish a dream of freedom." The slaves did not need the white Enlightenment doctrine of the Rights of Man to start a revolution, James contendss, thus significantly undercutting his Black Jacobins trajectiony.

6 For the influence of African political ideology on the Haitian Revolution, see John K. Thormtom, "I am the Subject of the King of the Congo:" African Political Ideology and the Hlaitian Rewollution," Journal off World Hitistromy, 4.2 (1993), 181-214t. For the role of vodum in the revolution, see Joan Dayan, Haiti, Hiistory and the Gods (Berkeley: University of California Press, 1995); Carolyn E. Fick, The Madking off Haiti.. The Saint Domuingue Revolution From Below (Knoxwillley TN The Umiversity of Temmessee Press, 1990); Michel S Laguerre, Voodoo and Politices im Haiti, (New York: St. Martin's Press, 1989). I use the spelling vodun to distinguish this syncretic AfroCaribbean religion from voodoo, the vicious parody that the Western media and Hollywood have made of it.

7 James, Black Jacobins, 69.

8 Ibid., 15. For a fascinating exploration into the history of this vodum chant and its many contrasting tramslatiomss, see Alasdair Pettimger, Maarit Forde and Diana Paton, ed., "Eh! Elh!" Bomba, Hem! Hen!:' Making Sense of a Vodou Chant,"' in Obeah and Other Powers: The Politics off Caribbean Religion and Healing (Durham: Dulke University Press, 2012), 80-1102.

9 James, Black Jacobins, 14. 
While James never resolves these ideological contradictions, it would clearly be wrong to regard his Black Jacobins as mere epigones of French Jacobins. On the contrary, they transformed and creolized French revolutionary ideol- ogy in what I would suggest were a series of productive misappropriations or mistranslations. The slaves did not just passively take up Jacobin ideas: instead, they radically appropriated and transformed them, often universalizing their limited reach. In particular, they modified the French Enlightenment idea of the Rights of Man and Citizen, originally limited to the white, male, bourgeois citoyens, and applied these to their situation as Afro-Caribbean slaves:

And meanwhile, what of the slaves? They had heard of the [French] revolution and had construed it in their own image: the white slaves in France had risen, and killed their masters, and were now enjoying the fruits of the earth. It was gravely inaccurate in fact, but they had caught the spirit of the thing. Liberty, Equality, Fraternity. ${ }^{10}$

Speaking as a ventriloquist for the slaves in the then French colony of SaintDomingue, James here contrasts the White Jacobins (or more precisely the lower-class sans-culottes) with the slaves whom he portrays as Black Jacobins. Slavery as a metaphor for exploited labor clashes and merges with actual New World chattel slavery. Without levelling the differences between Europe's peasants and proto-proletarians and the Caribbean chattel slaves, James nevertheless construes parallels between them that go beyond a merely metaphorical comparison. From his Marxist perspective, James locates slavery in the Caribbean and exploited labor in Europe on a global spectrum of exploitation. Not just their exploitation but also their resistance to emerging global capitalism as slaves, as lower-class Europeans, and as other diasporic Africans, were often related, as for instance Peter Linebaugh and Marcus Rediker demonstrate in their study of the transatlantic proletariat of the 'Red Atlantic."

However, there were key differences with respect to the lower classes in France and the slaves in the Haitian Revolution. It is indeed "gravely inaccurate" to portray French peasants as "white slaves" murdering their masters. For instance, as Pëtr Kropotkin asserts in his history The Great French Revolution (1909), ${ }^{12}$ which according to Christian Høgsbjerg forms a key intertext for

$10 \quad$ Ibid., 66.

11 See Peter Linebaugh and Marcus Rediker, The Many-Headed Hydra: Sailors, Slaves, Commoners, and the Hidden History of the Revolutionary Atlantic (Boston: Beacon Press, 2000).

12 Peter Kropotkin, The Great French Revolution 1789-1793 (London/New York: Putnam \& Sons, 1909). 
The Black Jacobins, the French peasant revolt of 1788/89 "confined its attention to things." ${ }^{\prime 3}$ By contrast, the slaves destroyed both their masters' property (which they were a part of) and killed their masters and their masters' families. While James historically inaccurately contends that "like revolutionary peas- ants everywhere, [the slaves] aimed at the extermination of their oppressors," slavery's terror regime did indeed require the extermination of their masters if the slaves were to retain any hope of keeping the freedom they fought for. ${ }^{14}$

Whereas the Saint-Dominguean slaves, thus, were clearly under a misapprehension when they regarded the initial peasant revolts of the French Revolution as slave revolts, James paradoxically claims that they grasped the essence of the French Revolution. What then was the "spirit of the thing," as James offhanded- ly and provocatively puts it, which led the slaves in the French colony of SaintDomingue to mount the massive slave revolt that marked the beginning of the Haitian Revolution? James' cryptic remark, I would suggest, refers to the radical reinterpretation of the Rights of Man and Citizen that the slaves undertook through their revolutionary actions. They radically extended the validity of these rights in terms of race and class, albeit not gender. ${ }^{15}$ Although stopping short of the goal of "universal emancipation,"16 the slaves adopted a considerably more radical, universalist interpretation of the Rights of Man than the bourgeois French revolutionaries had ever intended. As James suggests, it was this misappropriation that pitted the slaves into conflict with French revolutionary government until the 1794 abolition of slavery, which was, in turn, a result of the Haitian Revolution.

Moreover, the slogan of French Revolution, liberté, egalité, fraternité, had a fundamentally different meaning to the slaves than to the French bourgeoisie.

13 Christian Høgsbjerg, C.L.R. James in Imperial Britain (Durham NC:-Duke University Press, 2014), 82 .

14 C.L.R. James, The Black Jacobins: Toussaint Louverture and the San Domingo Revolution (2nd ed.) (London etc.: Penguin 2001), 69.

15 See Nick Nesbitt, Universal Emancipation. The Haitian Revolution and the Radical Enlightenment (Charlottesville: University of Virginia Press, 2008), for a philosophical-political investigation into the Haitian Revolution's promise of universal emancipation. For discussions of the gender limitations of the French and Haitian Revolutions, see Laurent Dubois, Gendered Freedom, "Citoyennes and War in the Revolutionary French Caribbean" in Karen Hagemann, Gesa Mettele, and Jane Rendall, eds., Gender, War and Politics: Trans-atlantic Perspectives, 1775-1830, (Houndsmill: Macmillans, 2010), 58-70; Shanti Marie Singham, "Betwixt Cattle and Men: Jews, Blacks and Women, and the Declaration of the Rights of Man" in D.K.V. Kley ed., The French Idea of Freedom: The Old Regime and the Declaration of Rights of 1789 (Stanford,CA: Stanford University Press, 1994), 114-153.

16 Nick Nesbitt, Universal Emancipation. The Haitian Revolution and the Radical Enlighten-ment (Charlottesville: University of Virginia Press, 2008). 
What was at stake for the slaves - in contrast to the French bourgeoisie and the Saint-Domingue colonists - was not economic liberalization or political representation; it was freedom from chattel slavery. Most importantly, the slaves referred to freedom in very palpable and tangible ways: not as some abstract idea, such as political freedom, but freedom from being mere objects and property of the masters, as was their legal status as chattel slaves. However, it would be an exaggeration to conclude, as Cedric Robinson does, that James implied that "bourgeois culture and thought and ideology were irrelevant to the development of revolutionary consciousness among Black and other Third World peoples."17

In contrast to Robinson, James follows Marx and does not repudiate the revolutionary achievements of the European bourgeoisie. Instead he emphasizes how the colonial subaltern, the African Caribbean, decisively contributed to what has often been misrepresented as the chronicle of European political thought: human rights. Instead of rejecting European bourgeois revolutionary ideology, James' Black Jacobins redefined, universalized and radicalized the Rights of Man (and thus exposed their racial and social limitations); they even went beyond the definition of "Liberty," meaning freedom from slavery rather than political freedom. "Equality" for them meant something very dif- ferent than it did for the French bourgeoisie. Rather than just calling for legal equality as citizens instead of being chattel slaves (in itself an unprecedented revolutionary demand), they called for even more: racial and social equality. "Fraternity" seemed to include an element of inter-racial, proto-proletarian solidarity with the "white slaves" of Europe. In sum, the slaves' misappropriation revealed the profoundly radical potential that the Rights of Man harbored.

These demands included an end not just to slavery, but to socio-economic exploitation per se. What the Black Jacobins, mistakenly, admired in their French brethren, the lower-class sans-culottes and the peasants, was that, post-revolution, they seemed to "now [be] enjoying the fruits of the earth." Their implicit call to end exploited labor and the alienation of the producers from the products of their labor by killing their masters went considerably beyond any form of bourgeois and republican radicalism. While the Black Jacobins conceived of slavery as the most exploitative form of labor, their call to enjoy the fruits of their labor was clearly a wider socio-revolutionary one, which has a long tradition throughout Europe. This exhortation to end alienat- ed labor moves considerably beyond Jacobin ideology and instead locates the Black Jacobins within a proto-communist trajectory.

17 Cedric J. Robinson, Black Marxism: The Making of the Black Radical Tradition (London; Totowa, A.J.: Zed; Biblio Distribution Center, 1983), 386. 
In the Anglophone context, the religiously-connoted phrase of enjoying the fruits of one's labor first came to prominence during the English Revolution, propagated by radical sects, such as the Diggers, who communally occupied and farmed common land. For example, in 1649 Robert Evered declared in court that "God would bring his people out of this slavery, and restore them to their freedom in enjoying the fruits and benefits of the Earth. ${ }^{n 18}$ At the time of the American Revolution, the British agrarian socialist Thomas Spence used this metaphor, too, as he indicted the exploiters of the laboring poor in his 1775 Newcastle lecture on the Rights of Man. In Britain, Spence maintained, it appeared as if the rich "had been created for the sole purpose of destroying the fruits of the earth. ${ }^{19}$ In The Rights of Infants (1796) he demanded that the rights of man must transcend the political sphere, and called instead for "rights [to] extend to a full participation of the fruits of the earth. ${ }^{20}$ In the same year, during the French Revolution, the early socialist François Noël Babeuf and his conspirators phrased in similar terms their critique against the exploitative mode of production for their campaign against private property. In the Manifesto of the Equals (1796) they demanded "the common enjoyment of the fruits of the land: the fruits belong to all."21

As this snapshot of the phrase 'fruits of the earth' in the European radical and early socialist tradition demonstrates, James deliberately placed his slave revolutionaries into a transatlantic, ultra-radical trajectory, far left of bourgeois republicanism. For James, the Haitian revolutionaries are as much Black Jacobins as Black Early Communists. While they employ the slogans of the

18 Peter Linebaugh and Marcus Rediker, The Many-Headed Hydra: Sailors, Slaves, Common-ers, and the Hidden History of the Revolutionary Atlantic (Boston: Beacon Press, 2000),

118. Linebaugh and Rediker assert that C.L.R. James was among "the students" of the $1647 / 48$ 'Putney Debates,' which included similarly radical socio-revolutionary demands voiced by the 'Levellers' among the soldiers (ibid., 108).

19 Thomas Spence, The Rights of Man, as Exhibited in a Lecture, Read at the Philosophical Society, in Newcastle, to Which Is Now First Added, an Interesting Conversation, between a Gentleman and the Author,... With the Queries Sent by the Rev. Mr. J. Murray, to the Society ... And a Song of Triumph for the People, on the Recovery of Their Long Lost Rights. The Fourth Edition. By T. Spence (London: printed for the author, 1793) 33.

20 Thomas Spence, The Rights of Infants; or, the Imprescriptible Right of Mothers to Such a Share of the Elements as Is Sufficient to Enable Them to Suckle and Bring up Their Young in a Dialogue between the Aristocracy and a Mother of Children. To Which Are Added, by Way of Preface and Appendix, Strictures on Paine's Agrarian Justice. By T. Spence, (London: printed for the author, 1797), 5.

21 Sylvain Maréchal, Manifesto of the Equals. (Accessed: April 24, 2014) http://www.marxists.org/history/france/revolution/conspiracy-equals/1796/manifesto.htm 
bourgeois French Revolution, they fill them with socio-revollutionary meaning that is diametrically opposed to the socio-economic system that led to the rise of the transatlantic boungeoisisie: the plantation economy. As the Black Jaco- bins moved decidedly beyond Jacobin radicalism, for James they became the vanguard of proto-proletarian revolutions on both sides of the Atlantic. Their proto-socialist, anti-colonialist redefinition of the Rights of Man advanced decisively beyond a liberal capitalist "pseudo-humanist" conception of human rights, a concept that is necessarily "narrow and fragmentanry, incomplete and biased and, all things considered, sordidly racist," as Martiniquan poet and intellectual Aimé Césaire insists in his anti-colonial manifesto Dïscourse on Colonialism (1955). 32

There might be another final misappropriation that James undeatralkes, for the specter of the slaves as "Black Jacobins' murdering their masters exists in contemporary discourse, even in Saiimt-Domingue itself. Before it was appropriated as a positive, revolutionary trope, it had already emerged as a counterrevollutionary trope of horror that demonized the slave rebels. Thins use even ppredates the Haitian Revolution. In September 1789, with the news of the storming of Bastille having freshly arrived in Saint-Domingue, the colony's intendamt (the civilian governor in charge of police, justice and finances) François Barbé-Marbois became increasingly concerned about the reactions of the slaves to the revolutionary events in the métropolle:

All that happens and that is being written about, especially about the emancipation of the negroes, becomes notorious in the colony ... these negroes agree with everything ... that the white slaves have killed their masters and that, now free, they govern themmellwes and retake possession of the goods of the earth.23

It is likely that this passage from the writings of the intendamt constituttes the direct source for the famous Black Jacobins passage in James' Black jacobina, James lavished praise on the source, the history that this passage stems from, $\mathrm{R}$ de Vasssière's work Saint-Dlomumungowe, 1629-1789 (1909), calling it "a master- piece of careful research and vivid representation. 24 James transformed this

22 Aimé Césaire, Disscourse on Colonialism, J. Pinkham, tramss. (New York: Monthly Review Press, 2000), 3.

23 Quoted in David P. Geggus, Slavery, War and Revolutiom: The British Occupation offSaint' Dommingewe, 1793-17988 (Oxford: Clarendon Press, 1983), 38; (translation RH).

24 C.L.R. James, The Black Jacobins: Toussatint Louverture and the San Dommingro Revolution (2nd ed.) (London etc.: Penguin 2001), 333. 
ominous warning of a slaughter of the colonialists and the destruction of plantations in the wake of the taking of the Bastille into a promise of transatlantic revolutionary emancipation.

To sum up, James placed the Black Jacobins at the center of transatlantic radical revolutionary thought and action, not merely for the Atlantic world of the eighteenth and nineteenth centuries, but right up to the twentieth century. Yet, to call the Haitian revolutionaries - if maybe not their leaders - Black Jacobins constitutes a misnomer, as they were closer to the sub-bourgeois sans-culottes; another "gravely inaccurate" misappropriation that according to Matthew Quest James subsequently became aware of, as he kept re-imagining "a class struggle of the 'Black Sans-culottes' in Haiti." ${ }^{25}$ For James, the Black Jacobins (or better Black Sans-culottes) become avant-garde figures for the entire revolutionary Black Atlantic, stretching from the Haitian Revolution through the African anti-colonial revolutions up to the Cuban Revolution. As I will show, James' emphasis on the figure of the Black Jacobin as a link between black transatlantic revolutionary struggles throughout the centuries is not just a figment of the imagination of a Marxist anti-colonial revolutionary intellectual and activist, but has a solid base in the revolutionary discourse of the late eighteenth and early nineteenth century. I will now particularly trace the shift in the connotations of the Black Jacobins from a trope of transatlantic counter-revolutionary horror to one of transatlantic revolutionary emancipation, a trajectory which ends, I argue, with James' Black Jacobins.

\section{Richard Newton's "A Real San Culotte!!" (1792): The Black Sans-culotte as the Gothic Specter of Transatlantic Revolution}

While the horror image of the Black Jacobins/Sans-culottes dominated contemporary accounts of the Haitian Revolution, it is vital to acknowledge that, at least for a short while, before and after the 1794 French abolition of slavery, the trope of emancipation and the Black Jacobins emerged and existed in a more positive light in French discourse and visual culture. Sculptures and im- ages depicted grateful liberated slaves wearing caps of liberty and asserting in broken French: "Moi, égale/libre aussi" (I equal/free, too). These images im- plied that the slaves had been emancipated and endowed with equal rights by

25 Matthew Quest, "On 'Both sides of the Haitian Revolution'? Rethinking direct Democracy and national Liberation in The Black Jacobins," in Christian Høgsbjerg \& Charles Forsdick eds., The Black Jacobins Reader (Durham, NC, Duke University Press, 2017), 235-255; here 236. 

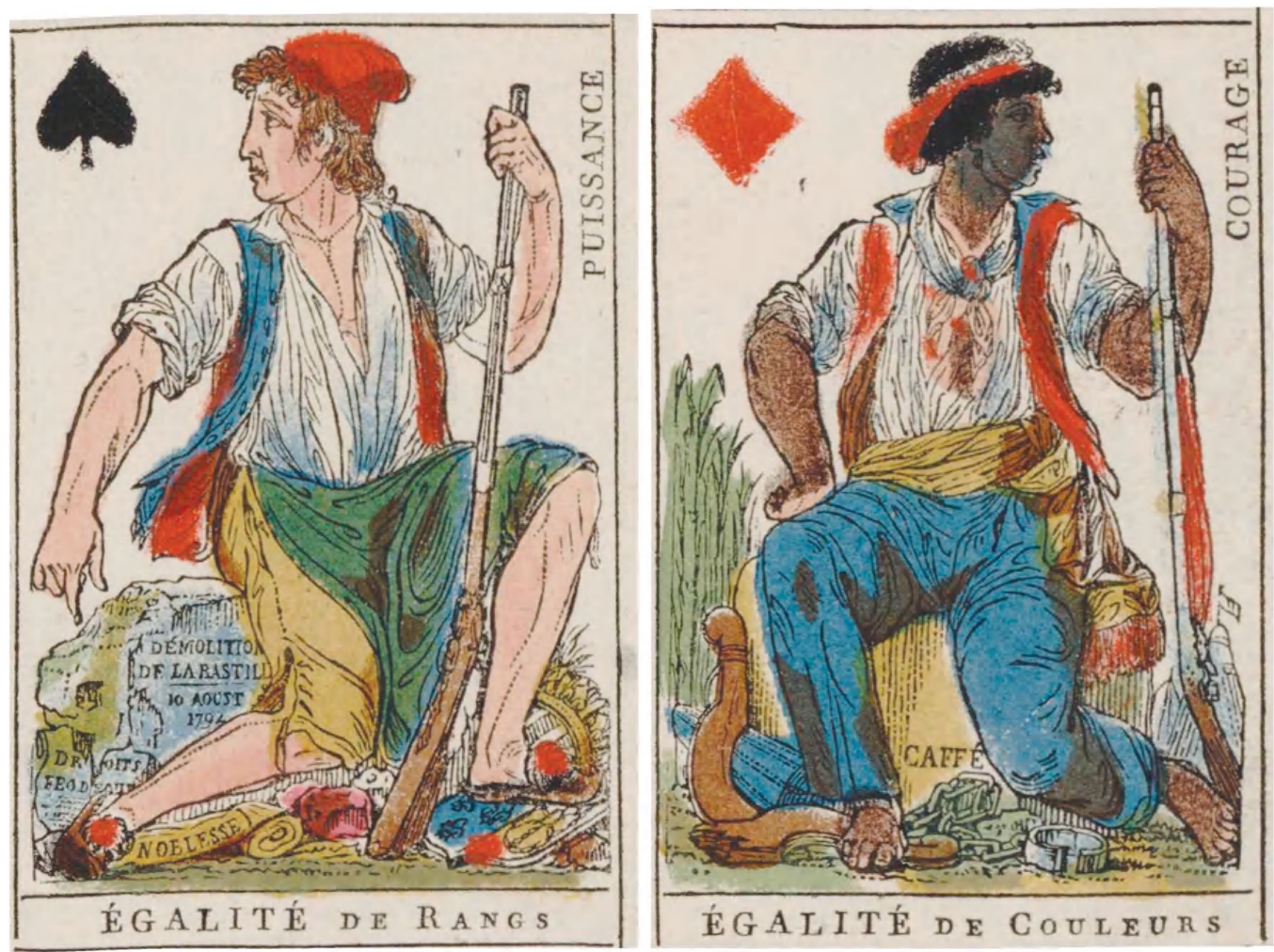

Illustration $1.1 \quad$ Nouvelles cartes de la Republique française. An advertisement for French Revolutionary Playing Cards (Paris: U. Jaume et J.D. Dugourc, 1793-94) (details), (C) bibliothèque nationale de france

the grace of the French Republic. Sometimes, the images even made explicit comparisons with the sans-culottes. In an advertisement for a deck of revolutionary playing cards, a sans-culotte sitting on boulder from the Bastille forms the Jack of Spades, while a black figure with a rifle, sitting on a sack of coffee, forms the Jack of Diamonds (Illustration 1.1).

In the advertisement, the sans-culotte is associated with "puissance" (pow- er or strength) and epitomizes the "equality of ranks." In contrast, the Black sansculotte is associated with "courage" and epitomizes "equality of colors." In short, together they symbolize an idealized republican vision of the equality of class and race. Problematically, the advertisement, instead of using the more neutral noir (black), refers to "le Nêgre [sic]," which in French carries even more racist connotations than its English translation, which is negro. Clothed in the colors of French republican tricolore, the black sans-culotte is wearing a ban- danna, which can be read as echoing a creolized version of the sans-culotte's cap of liberty. Both figures apotheosize the emancipatory power of the French Republic rather than celebrating the revolutionary self-emancipation of the SaintDominguean slaves. Instead, the black sans-culotte is cast, as the bottom 


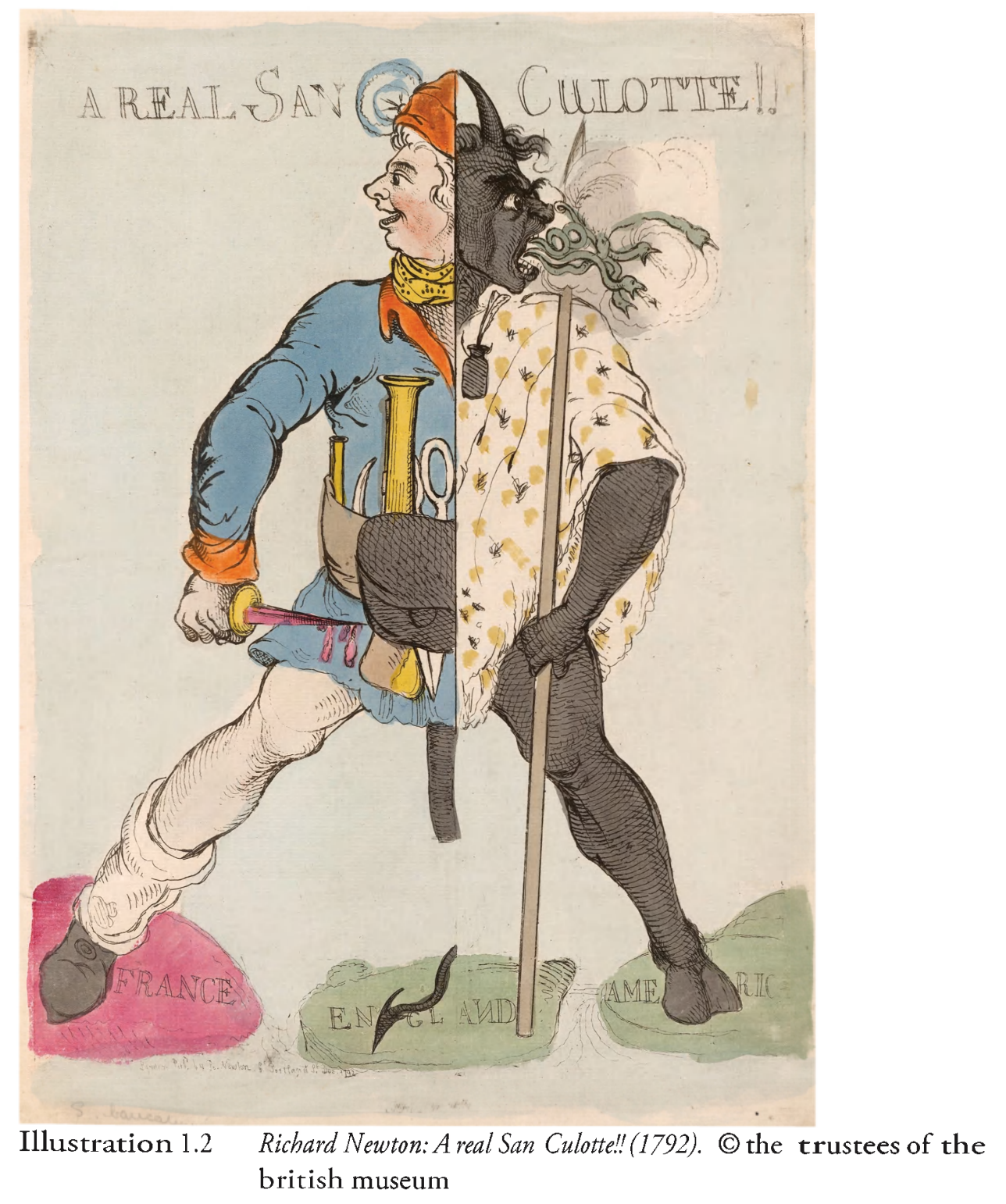

right corner of the image suggests, in the role of a foot soldier of the French Revolution protecting French colonial commodities such as coffee.

In British contemporary visual culture, however, such a - however compromised - shift in the trope of Black Jacobins away from the horror image did not occur. The contemporary image that encapsulates British anxiety about the transatlantic revolutionary threat posed by the Black Jacobins perhaps most strikingly is the caricature "A Real San Culotte!!" (1792) (Illustration 1.2). Unlike the French cards, in this caricature the Black and the White sansculottes are merged into one figure. The print is the work of Richard Newton, a fifteen-year old engraver working for the London publisher William Holland. However, this print was published under Newton's name rather than Holland's 
in December 1792, the month Holland was arrested for publishing Thomas Paine's banned defense of the Rights of Man (1791-92). As the title of the caricature suggests, the figure depicted was no bourgeois Jacobin, but rather a decidedly lower-class sans-culotte:

It is striking how the artist employs the image's central visual device, the split figure: the left half consists of a ruddy and lusty lower-class French revolutionary, a sans-culotte, while the right half is made up of a devilish Africanized warrior figure. The sans-culotte's foot is placed on "France," which seems to have been reddened by revolutionary bloodshed. ${ }^{26}$ At closer inspection we discover the lower end of the figure's stockings and the sole of his shoe even seem to have been stained with the blood that he and the other sans-culottes have shed. He is wearing a cloth belt from which a blunderbuss, a smaller firearm, shears and scissors are protruding. The point of the scissors is obviously a phallic symbol that points towards the devil's tail attached to the right half of the split figure. On his belt, the sans-culotte is wearing a pouch which seems to be made out of the same bluish, black scaly skin that characterizes the figure on the figure's other half. He sports a cap of liberty on his head with a revolu- tionary cockade attached and holds a dagger in his hands from which blood is dripping: drops threaten to fall onto "England."

His liberty cap is joined at the top with the horns of the monstrous figure on the right, which displays typical attributes of the devil. Its cloven hoof is firmly placed on "America" and he spits fumes as well as little snakes. His devil's tail disappears into the Atlantic and re-emerges off the coast of England, with its pointed tip wiggling around the English soil. As well as being a devil, he is also characterized as a person of African descent through various clichéd accoutrements: he holds a spear as a weapon, wears an Africanized garb, and carries a fetish or medicine pouch around his neck. Even his dress mirrors his ambiguous status, vacillating between devil and black rebel. If you look very closely at his Africanized dress, the pattern appears to consist of little images of flies, which could refer to his satanic status as the biblical Lord of the Flies, or Beel-zebub. This ambiguity even extends to his skin. With its scaly, reptilian quality, it evokes a devil's skin, while its bluish-black color points to a person of African descent. As Marcus Wood points out, Newton used the same bluish-black tone to depict both satanic and black figures in his other works. ${ }^{27}$

26 I am thankful to Miranthi Huwae for pointing out the significance of the color scheme of countries or continents in the print.

27 Marcus Wood, Blind Memory: Visual Representations of Slavery in England and America (Oxford: Oxford University Press, 2000), 158. 
What are we to make of this caricature, and whom does the hybrid figure on the right-hand side represent? I believe that to answer these questions it is crucial to consider the key visual device of the print, the split figure, as well as the transatlantic revolutionary situation during which it was printed. The socio-political situation both in the Caribbean and in Europe was highly volatile: the French King had been taken prisoner after the storming of the Tuileries by the Parisian masses in August 1792, the Allied attack on revolutionary France had been repulsed in September, France had been declared a Republic and the September Massacres (largely committed by sans-culottes against prisoners, including priests and members of the nobility) had raised the specter of violent class war - also in Britain. The revolution had entered its second, much more radical phase, during which the bourgeoisie and the lower classes increasingly clashed. In the Caribbean, in the French colony of SaintDomingue (the Caribbean's then most profitable colony), the authorities had failed to quell a massive slave revolt that had started in August 1791, and which was now spreading to the neighboring French islands. The British West Indies were also in a state of high alert, fearing the spread of slave revolution. To summarize: at the time this caricature was printed, Britain and especially the British establishment felt threatened by the twin specters of transatlantic revolution, by the French and Haitian Revolution.

Newton's print expresses these fears in a grotesque, caricatured way, which taps into the widespread demonization of the French and Haitian Revolutions in anti-revolutionary print and visual culture. ${ }^{28}$ It partakes in what I call the "hegemonic Haitian Gothic," a discourse on the Haitian Revolution in print and visual culture, that is replete with tropes of horror and of terror. It aims to cement the transatlantic status quo of the slave economy by demonizing the severe challenges that the Haitian Revolution posed to it. ${ }^{29}$ To put it bluntly,

28 For the Haitian Revolution and the Gothic, see Matthew J. Clavin, "Race, Rebellion, and the Gothic: Inventing the Haitian Revolution," in Early American Studies, 5.1 (2007): 1-29; Ellis Markman, The History of Gothic Fiction (Edinburgh: Edinburgh University Press, 2000); How- ard L. Malchow, Gothic Images of Race in Nineteenth-Century Britain, (Stanford, CA: University of California Press, 1996); Lizabeth Paravisini-Gebert, "Colonial and Postcolonial Gothic: The Caribbean". J.E. Hoggle, ed., The Cambridge Companion to Gothic Fiction, (Cambridge: Cambridge UP, 2000), 229-258. For an overview of Gothic anti-revolutionary caricature in Britain, see, Ronald Paulson, "The Severed Head: The Impact of French Revolutionary Caricatures on Britain," in Grunwald Center for the Graphic Arts ed., French Caricature and the French Revolution, 1789-1799 (Los Angeles: Regents of the University of California, 1988), 55-65.

29 For a detailed exposition of the "Haitian Gothic," see Raphael Hoermann, "A Very Hell of Horrors'? The Haitian Revolution and the Early Transatlantic Haitian Gothic," in Slavery \&Abolition 37.1 (2016): 183-205. 
with its use of the Gothic it suggests that revolutionary self-emancipation amounts to anarchy, a descent into savagery and a diabolical terror reign by the black ex-slaves.

Newton's print employs the well-established device of the split figure to great effect in order to evoke such Gothic horror. One half usually reveals the true essence of the other ${ }^{30}$ - here we have a cheerful sans-culotte on the left being exposed on the right as a menacing black figure, half devil, half African rebel. "The Real San Culotte!!," as the title of the print underlines, turns out to be the devilish slave revolutionary rather than the jolly French sans-culotte.

The transatlantic dimension of Newton's print becomes apparent further if one compares it to another British contemporary print depicting a sans-culotte as a split figure. In the same month as Newton's caricature, December 1792, Isaac Cruikshank, one of London's leading caricaturists and father to the even more famous caricaturist and illustrator George Cruikshank, published a com- parable caricature: "A Right Honourable Alias A Sans Culotte" (Illustration 1.3). This caricature depicts the radical and colorful, but still respectable, British Member of Parliament Whig politician Charles James Fox on the right side. On the left side, Fox is revealed to be a disreputable, sinister sans-culotte wielding a cudgel in his hand.

The resemblance to Newton's print is striking. In some ways, Cruikshank's caricature is an exact mirror image of Newton's print, with the sans-culotte on the right rather than on the left side. However, there are also key differences. In Cruikshank's image, it is the sans-culotte who embodies the worst fears of revolution. It is the specter of class war that is conjured up, and the radical upper-class parliamentarian is accessory to it. Newton already starts with the strongly demonized figure of the sans-culotte, who is revealed to be an even worse character: a black devilish slave rebel. What Newton adds in his caricature is thus the specter of race war on top of class war. He takes the much-maligned figure of the sans-culottes, pretending to portray him in a more sympathetic light, but in truth demonizes him all the more by revealing him to be the devilish black Haitian slave rebel. In a high- ly racist way, his use of the "old graphic device of splitting a figure down the middle to reveal true identity" casts the African diasporic slave rebel as a figure of ultimate evil. ${ }^{31}$ At the same time this depiction demonizes the

30 See, Marcus Wood, Blind Memory, 158.

31 Ibid. 


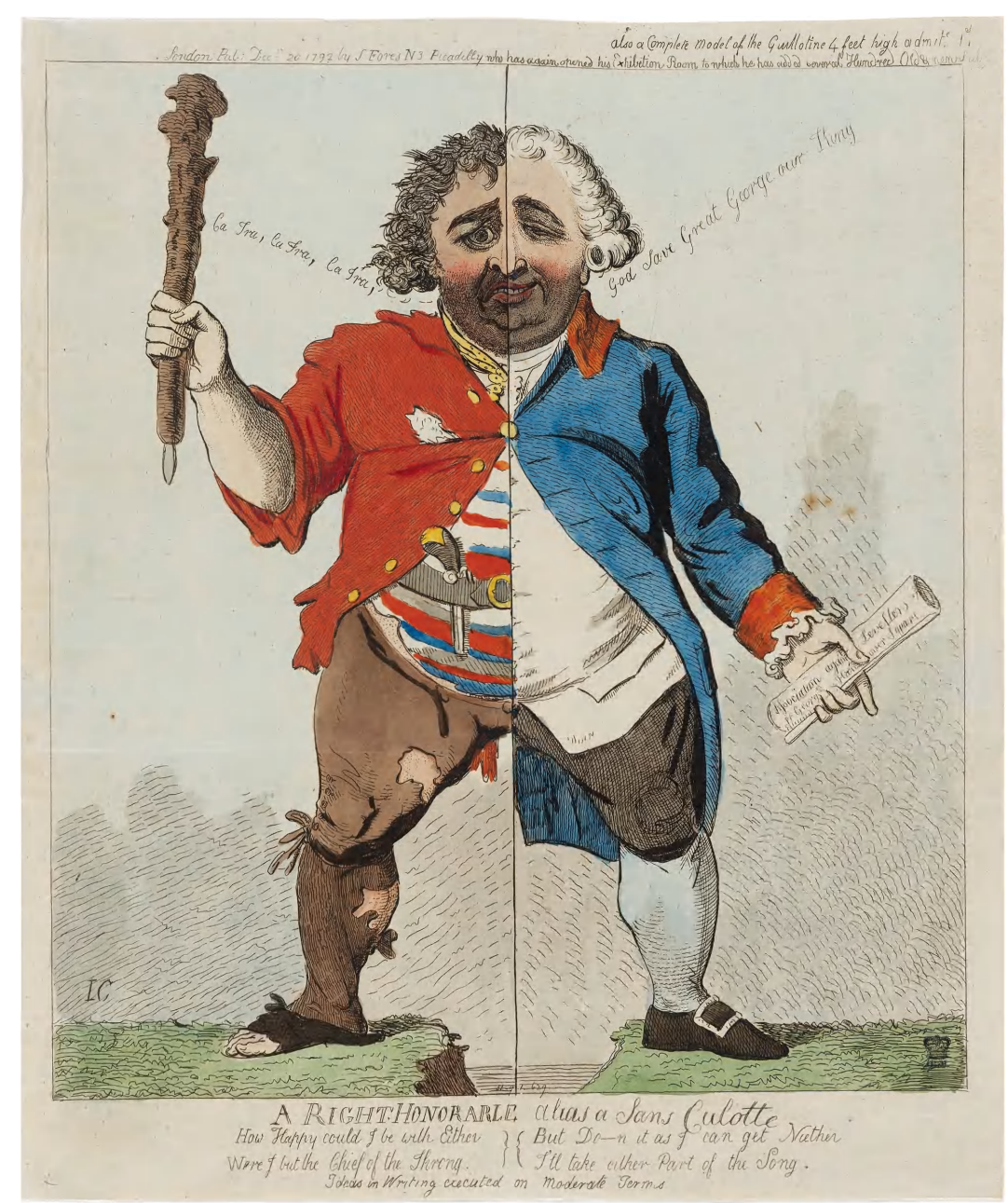

Illustration 1.3 Isaac Cruikshank: A1 Right H(Hommable Allivas \& Sams Culotte (1792)).. (C) the unustwees of the british museum

French lower-class revolutionamies. It implies that these white figures carry the black satanic revolutionaries in themn, thus quasi-equating French and Faitian revolutionariles within the moral hierarchy of Whitte classist and racist ideollogy.

Newton leaves little doubt that the devilish figure on the right constituttes indeed a caricature of a Saint-Domingue's slave revolutionanyy. By placing his hoof firmly on America, Newton stresses that this is a caricature of a figure from the African diaspora, more precisely a slave. The pun in the titlle San Culotte, with the missing " $\mathrm{B}$ " in Sans, might further be an allusion to San(to) Domingo, the English colonial name for Haiti. Some interpreters have stressed the alleged ambiguity of the image, and consequently claimed that it might constitute "an ironic comment on fears of Rewollution" or an umwidllingly 
executed, commissioned "anti-French print".32 The British Museum catalogue description states even more bluntlly: "Satire on the fears of Revollution." Such conjectures are inadequate, precisely because they completely ignore the eth- nie identity of the devilish figure of the slave rebel. I cannot detect any sign of irony in this print that would counter the demonization of the sans-culotte, let alone the slave rebel. In fact, the lack of irony becomes even more appar- ent if we situate the print within Newton's oeuvre: Newton strongly warns of the spread of slave revolts throughout the British West Indlies in another car- icature, "The Blind Enthussiast," also from the year 1792, in which he mocks the British abolitionist MP William Wilberforce. In this image, Newton's satire is mostly directed against the abolitionists and the slaves, not the slavehold- ers. In a third print, in the viciously racist caricature "Cruelty and Oppmession Abroad" (1792), Newton attempts to debunk accounts of the horrors of slavery circulated by abolitionists. In this image, Newton insists that the abolitionists' accounts are propagandistic fabrications, while in reality the happily dancing

"Negro' slaves lead a charmed life. Even when Newton seems to criticize the excesses" of slavery, as in "A Forcible Appeal for the Abolition of the Slave Trade" (1792), it is the black slave drivers with their caricatured evil looks whipping the slaves who are the real villains of the piece and not the white slave owners. As these examples show, it is extremely unlikely that Newton meant "A Real San Culotteen!" ironicallly, since all depictions of black people in his prints are strongly and viciously racist. Newton might demonstrate a tinge more sympa- thy towards the French sans-culotte in his primtss, but, as has been pointed out, the logic of the split figure strongly counters this. What Marcus Wood observes with reference to Edmund Burke's conflation of white and black Jacobinism equally applies to Newton and his print "A Real San Cullotted!n:" "he operattes a satiric miscegenation in which the black Jacobins are the demonic extension of white Jacobinism, the revolutionary devil you don't know engendered by the one you do." 33

What "A Real San Culottre!!" most forcefully expresses - beyond any ambigu- ity - is the deep-seated fear of a twin specter of transatlantic revolution. The threat posed to Britain from the lusty sans-culottes is obvious, since the blood on his dagger is about to drop on British soil and will eventually drench England in blood as well. Hower, the Saint-Domingue rebel is also threatening Briitain and its colonial empire with his devilish serpent tail. America still appears as

32 David Alexander, Richard Newotton and Emolish Caricature im the 1790s (Manchester: The Whitworth Art Galleryy, Manchester University Press, 1998), 118.

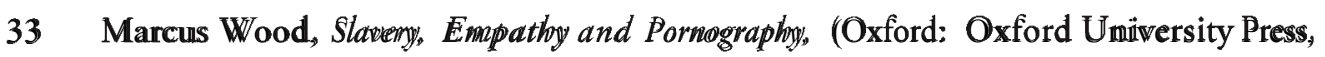


green as England, thus it is, in spite of the earlier American Revolution, yet untainted by the revolutionary bloodshed that has engulfed and reddened the map of revolutionary France. While the slave revolt in Saint-Domingue obviously challenged the slave regimes of the Americas, these events even threatened the British mainland, as the caricature suggests. The devil's tail disappears in the Atlantic (its submerged shape is faintly, barely visibly, traced in pencil), resurfacing off the coast of Britain and wiggling over its soil with its tip pointing towards London. "A Real San Culottel!" evokes a transatlantic specter of revolution in which the French sans-culotte and the Black sans-culotte, the SaintDomingue slave rebel, merge into one figure of transatlantic revolution- ary memace. Together, they threaten the transatlantic status quo: the British monarchy and its regime on the eastern side of the Atlantic, and colonialism and slavery, the mainstays of the transatlantic economys, on the western side of the ocean.

\section{Edmund Burke's Counterrevolutionary Invectives against the Black Jacoobins in Letters on a Regicide Peace (1796) and James Gillray's caricature "Promised Harrors of a French Invasion"(1796)}

The anti-revolutionary trope of the Black Jacobins was not limited to visual culture. Most notorious in the British context are arguably Edmund Burkes vitriolic attacks on the Saint-Domingue rebels. In his infamous diatribe against the fledgling French Revolution, Reflections on the Revolution in France (1790), Burke had already prophesied that the French Revolution would lead to anti-colonial revolutions by the colonists. This in turn would trigger a slave revolution: "As the colonists rise on you, the negroes rise on them. Troops again-Massacre, tortune, hangimg!' These are your rights of men!"34

By implying that the Rights of Man would lead to the revolutionary overthrow of colonialism and slavery, Burke here emphasized the explosive power that lay in their universalist interpretation. More astutely than many of the contemporary revolutionarities, the staunch counterrevolutionary Burke recognized that the doctrine of the Rights of the Man had the potential to function as one of the ideological triggers for slave revolution. In revolting, the slaves claimed these rights for thermselves, which were never intended to apply to them. While Burke deeply detested any form of ppopular revolution, either by slaves or by the European masses, in his ominous warning of colonial and slave revolution he ironically came very close to James" assertion the slaves caught "the spirit of thing" in their revolution: a universalist interpretation of the "Rights of Man" beyond its class and race limitatioms.

34 Edmund Burke, Select Works offEdmund Burke, E. J. Payne \& F. Canavan, eds., vol. 2 (Indianapporlis: Liberty Fund, 1999 
When the Haitian Revolution did break out, Burke felt vindicated and unsurprisingly spat vitriol all over the pages of his final work Letters on a Regicide Peace (1795/96). Half-crazed already, he created his own Black Jacobins, mirroring in the ferocity and depravity of their sans-culotte cousins, the "cannibals of Paris."35

Burke depicted the Saint-Domingue slave revolutionaries as key figures in a hell- ish revolutionary pantheon consisting of "rebels, traitors, Regicides, and furi- ous negro slaves, whose crimes have broke [sic] their chains. ${ }^{n 36}$ White and Black Jacobins were united by their depravity. They shared - what I want to call - the same 'black moral skin color.' As Wood concludes: "Slave/savage and Jacobin/ savage, white/Jacobin and black/Jacobin are conjoined, and through their ideo- logical union ironically attain a charged equality in iniquity. ${ }^{137}$ In Burke's depic- tion, just as in Newton's "Real San Culotte!!" both the French and Black Jacobins posed a severe threat to Britain. Alluding to the British military campaign in SaintDomingue, which was eventually defeated by Toussaint Louverture and his troops, Burke melodramatically lamented the slaughter of the "pride and flower of the English nobility and gentry" at the hands of "tribunals formed of Maroon negro slaves, covered over with the blood of their masters, who were made free and organized into judges, for their robberies and murders. ${ }^{138}$

While Burke's anti-revolutionary sentiment struck a chord with parts of the British establishment among British contemporary radicals, Burke's ferocious racism and classism had its detractors. For instance, Marcus Wood and I have shown how one British radical, John Thelwall, debunked and satirized the histrionics of Burke's counterrevolutionary rhetoric and his demonization of French and Black Jacobins, even though he stopped short of endorsing the revolutionary violence of either White or Black Jacobinism. ${ }^{39}$

35 John Thelwall, The Politics of English Jacobinism: Writings of John Thelwall, Gregory Claeys, ed. (University Park: The Pennsylvania State University Press, 1995), 308.

36 Edmund Burke, Select Works of Edmund Burke: A New Imprint of the Payne Edition, F. Canavan \& E. J. Payne eds., vol. 3, (Indianapolis: Liberty Fund, 1999), 142.

37 Marcus Wood, Slavery, Empathy and Pornography, 157.

38 Edmund Burke, Select Works Vol. 3, 142.

39 Raphael Hörmann, "Thinking the 'Unthinkable'? Representations of the Haitian Slave Revolution in the British Discourse, 1791 to 1805," in Raphael Hörmann, Gesa Mackenthun, eds., Human Bondage in the Cultural Contact Zone: Transdisciplinary Perspectives on Slavery and Its Discourses (Münster, etc.: Waxmann, 2010), 158-164; Marcus Wood, Slavery, Empathy and Pornography, 171-177. 


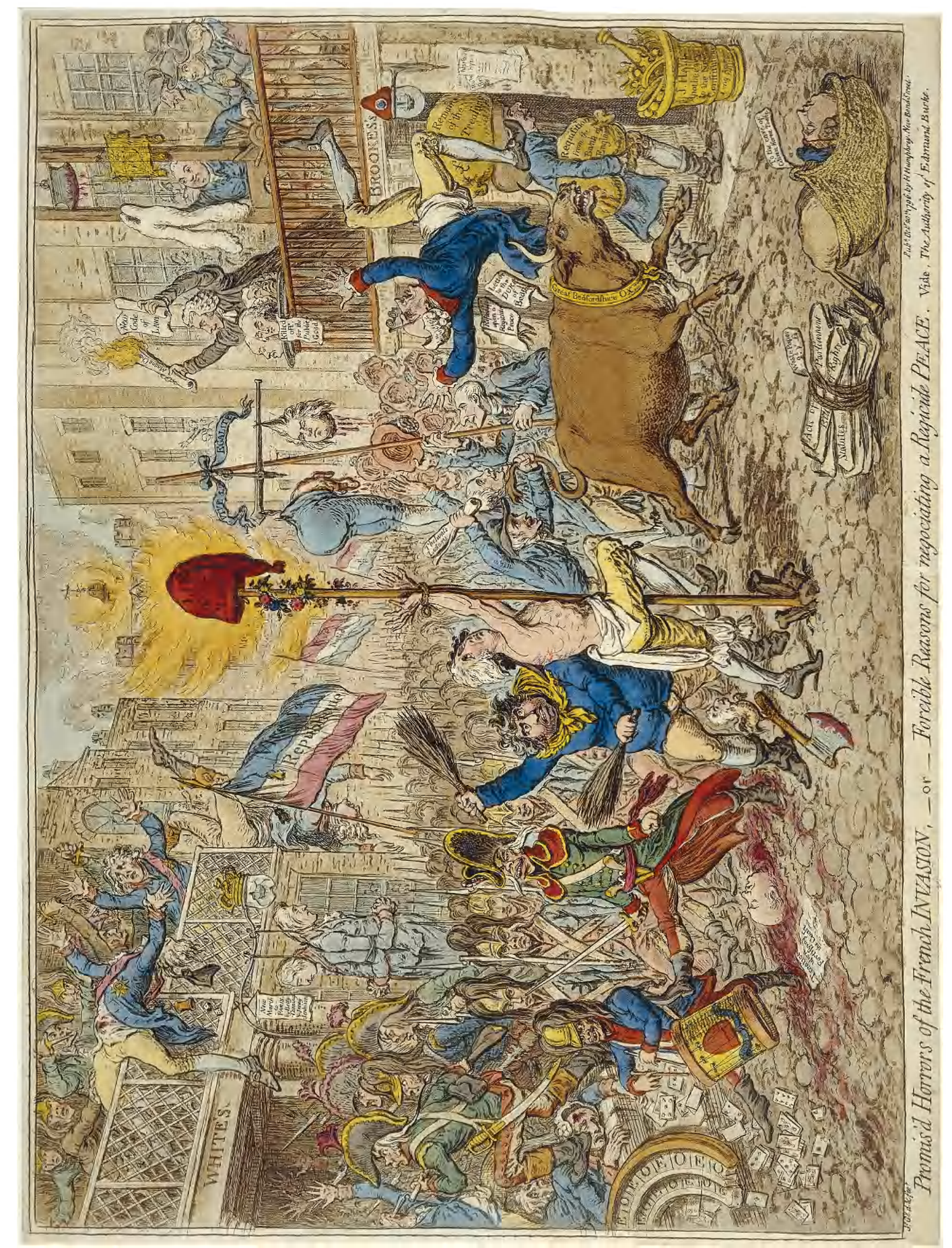

Illustration 1.4 James Gillray: "Promis'd Horrors of a French Invasion, - or - Forcible Reasons for Negotiating a Regicide Peace, Vide, The Authority of Edmund Burke" (1796). (C) the trustees of the british museum

Looking at James Gillray's highly Gothic caricature "Promis'd Horrors of a French Invasion, - or - Forcible Reasons for negotiating a Regicide Peace, Vide, The Authority of Edmund Burke" (1796) (Illustration 1.4), the stance taken towards Burke's diatribe is less obvious, if clearly less radical. 
Gillray was evidently aware of the controwersy between Theelwwall and Burke, as both feature prominently in his print. Using his "Lectures" as a whip, Thellwall is driving the radical oxen (a symbol for Burke's arch-ememy, the Duke of Bedford) through the streets of a burning London, which is in the grip of the French revolutionary invasion. Burke is being kicked off a balcony and is about to be impaled on the horms of the radical ox. Falling with him is a pamphlet entitled Reflections upon a Regicide Peace, a confila- tion of Burke's Reflection on the Revolution in France and his Lettens on a Reg-icide Peace. In an intertextual/imtentwisual circle, Gillray s print could in itself even be said to form an illustration of Burke"s "Gillrayesque leap of the imag- ination" horrific scenario of England after the feared French invasion, which Burke so colorfully conjumes up in his Letters on a Regicide Peace. Both Burke's texts and Gillray"s print,, which shows the "desolated" city of London swarming with Burke's dreaded revolutionary savages include bloodthirsty tribumanls, consisting this time not of Black but French Jacobins as judlgess:

the law totallly, fundammemtalllyy, and in all its parts destroyed; the judgeses put to death by revolutionary tribumalls; the Peers and Commoms robbed to the last acre of their estates; [...] the desolated cities, the wasted fields, and the rivers polluted with blood [...].41

Again, Black and White Jacobins are closely linked. Burke's apocalyptic scenario of revolutionary carnage and anarchy inflicted upon the British establishment by French invaders ends with the aforementioned indictment of the Black Jacobins as murderers of the English upper classes in Saint-Domimgure. These were condemned to death by criminal and murderous "tribumalls formed of Maroon negro slaves, covered over with the blood of their masters."

Howerer, it was not just Burke who conjured up the horror of the Black Jacobins, which he merged with that of the White Jacobins. I would argue that Gillray was an astute reader of Burke and, as such, he not only integrated revolutionary tribumalls, but also Black Jacobins into his print. If you look closely, a number of the soldiers of the French army are caricatured with simian facial features. In particular, the goose-stepping officer (stepping over a severed head) bears features that were used in contemporary racist caricatures to depict black people, such as a broad, flat nose and thick, bulging lips. This racial slur becomes all the more poignant if one considers that in the French Revolutionary army (unlike

40 Marcus Wood, Slawemy, Emppathy and Pormographoy, 157.

41 Edmund Burke, Select Works Vol. 3, 142.

42 Ibi 
in the British) some mixed-race soldiers rose to high ranks. Not only was the renowned swordsman, abolitionist and composer Chevalier de Saint-Geonges the commander of a short-lived all-Black legion named after him -Légion de St.Georges - but also his secomd-in-command Alexandre Dummas, father of the eponymous famous novelist, rose to one of the highest ranks in the French Army, becoming division general of several armies. It is not at all improbable that Dummas would have commanded a French army sent towards England, as he had commanded several French military campaigns. While this close rival of Napoleon was an extremely prominent figure during his own time, he and other mixed-race participants of the French Revolution have virtually been written out of the official history of the French Revolution.43I believe that, giv- en the prominemce of these two mixed-race officers, there can be very little doubt that Gillray refers to these and other Black Jacobins in the French armmy, even more so since the commander in the caricature is wearing a uniform in the colors of the Légion des St. Georges, red and green.44 Since he seems to be commander of the French invading army, this figure might very well represent a caricature of General Alexandre Dummas, who originally hailed from Saint- Domingue and was the son of a noble plantation owner and one of his slaves. As in the works of Burke and Newton, in Gillray's caricature the Black Jacobins also form the ultimate Gothic trope of revolutionary terror. They are marching through the blood-soaked streets of a ransacked and pillaged London, whose establishmentfigures they either guillotine or lynch. As with Burke, white and black Jacobins alike become the ultimate horror tropes of revolutionary terrror. As is implied in both, if Jacobinism were to take over Britain, the consequence would be nothing short of a secular apocalypse, a complete meltdown of all po- litical and social order. Similarly to Newton, Burke and Gillray also merge White and Black Jacobins, the European and African savages,' into one looming figure of transatlantic revollutionary menace. This combined figure threatens to an- nihilate the British Empire from its class system to its economic base, which consisted in colonial slavery and the triangular trade, including the slave tradle.

Hower, there might be even the warning about a potentially destabilizing effect of the continuing slave trade, when the tortumes of the plantation slave regime are evoked in the depiction of Prime Minister William Pitt the Yoomnger, half-stripped being whipped at a Liberty tree by the aforementioned MP Charlles James Fox. In a 17911 caricature, "Barbarities in the West-Indties," Gill- ray had attacked the excessive cruelty of some planters by depicting a planter

\footnotetext{
43 Tom Reiss, The Black Count: Glory, Revolution, Betrayal and the Real Count off Monte Crists (London: Vintage Books, 2013).

I am grateful to Lubaina Himid for pointing out the significance of these uniform colors.
} 
throwing a slave into a vat of boiling sugar syrup. Yet again, Fox, painted with a dark skin color and frizzy hair, might just constitute another sans-culotte figure closely related to the Black Jacobins or Black sans-culottes. In fact, Gilray in another related caricature, "Consequences of a Successful Invasion" (1798) depicts the French Jacobins establishing a regime of plantation slavery in England complete with whips and French slave drivers, with one explicitly likened to a "negro driver" who whips the "English slaves." For Gilray it seems, tapping into the trope of the Black Jacobins serves to further fan hysteria of a French invasion and a revolution in England, which he depicts as a monstrous enslavement of the 'freeborn' Englishmen, including the peasantry.

\section{4 "The Fate of St. Domingo Awaits You": Robert Wedderburn and his Vision of Transatlantic Proto-Proletarian Revolution}

The mixed-race, ultra-radical abolitionist and revolutionary preacher Robert Wedderburn (1762-1835/6?) recognized more clearly and indicted more angrily than any other early-nineteenth-century British commentator the interactions between race and class oppression and exploitation that propped up the British Empire. Wedderburn constituted a key player in the London ultra-radical underground, particularly during the $1810 \mathrm{~s}^{45}$ As a radical abolitionist, ${ }^{46}$ however, he should also be considered a pivotal figure of the Black Atlantic. ${ }^{47}$ I would argue that he also played a key role in the development of the trope of Black Jacobinism, for not only did he understand the intersectionality between race and class op- pression (if not gender), he was also one of the first in Britain to embrace the so- ciorevolutionary violence of Black Jacobinism. This placed him in sharp contrast to earlier British radicals, such as John Thellwall, who displayed great sympathies for the Black Jacobins, but ultimately did not condone revolutionary violence, be it by the White or Black Jacobins. ${ }^{48}$ Conversely, some radicals even demonized the slave revolutionaries, contrasting them with the oppressed peace-loving British

45 Iain McCalman, Radical Underworld: Prophets, Revolutionaries, and Pornographers in Lon-don, 1795-1840 (Cambridge: Cambridge University Press, 1988).

46 Iain McCalman, "Antislavery and Ultra-Radicalism in Nineteenth Century England: The Case of Robert Wedderburn," Slavery \& Abolition, 7.2 (1986): 99-117.

47 Michael Morris. Scotland and the Caribbean, C.1740-1833: Atlantic Archipelagos (New York: Routledge, 2015), 174-186; Alan J. Rice "Ghostly and Vernacular Presences in the Black Atlantic" in E.T. Bannet and S. Manning, eds., Transatlantic Literary Studies, 16601830 (Cambridge University Press, 2012), 154-168, here 161-166. 
peasants, whose fate, they suggested was worse than that of the Caribbean slaves.

Most notoriously, William Cobbett advanced such a position while he conjured up Gothic scenarios of genocide during the Haitian Revolution, warning ominously that Jamaica would soon be in the throes of slave revolution, too. ${ }^{49}$

Wedderburn expressed his ultra-radical position first in his short-lived journal with the programmatic title, The Axe Laid to the Root, or A Fatal Blow to Oppressors, Being an Address to the Planters and Negroes of the Island of Jamaica (1817). The journal's biblical title of the axe laid to root (cf. Luke 3:9, Matthew 3:10) draws upon an English radical tradition stretching at least as far back as Thomas Paine. Yet, this image also has a Black Atlantic dimension, such as in the founding father of Haiti, Jean-Jacques Dessalines, who in an 1804 declara- tion praised the Haitian Revolutionaries for having "carried the axe onto the ancient tree of slavery and prejudice. ${ }^{.50}$ The journal's even more menacing sub- title more openly demonstrates the transatlantic and Black Atlantic dimension of his periodical. Ostensibly directed towards the inhabitants of Jamaica, both the planters and the slaves, the journal's most immediate audience, however, were the subaltern working men in England - artisans and workers of London, where the journal was published. As the title already subtly suggests, by using the plural in "Oppressors," Wedderburn was fighting a double-campaign here. On the one hand, the journal was directed against the slaveholders and the sys- tem of colonial oppression in the West Indies. On the other hand, the articles attacked the repressive monarchical system in Britain and the increasing proletarianization of artisans and, increasingly, the severe exploitation of workers by capitalists. As Wedderburn insisted, in the same way as European slavers enslaved Africans, capitalists "employed them [the English poor] in their Cotton factories to make Slaves of them." As he declared in the bold opening sentences of his journal, he charged any individual and institution who should contravene his more universalist Black Jacobin interpretation of the "Rights of Man" with a severe criminal offence:

This Wedderburn, doth charge all potentates, governors, and governments of every description with felony, who does wickedly violate the

49 See Wood, Slavery, Empathy, and Pornography, 152-69.

50 Jean-Jacques Dessalines and Juste Chanlatte, Liberté ou la mort: Proclamation. Jean-Jacques Dessalines, Gouverneur Général aux habitans d'Haïti (Cap-Haïtien: P. Roux, 1804), https:// haitiandeclarationofindependence.files.wordpress.com/2013/08/dscf9464.jpg [accessed 10/10/2015]; (translation RH).

51 Robert Wedderburn, Horrors of Slavery and Other Writings, ed. Iain McCalman (New York: Marcus Wiener, 1991), 114. 
sacred rights of man - by force of arms, or, otherwise, seizing the persons of men and dragging them from their native country, and selling their stolen persons and generations. ${ }^{52}$

For Wedderburn, the slave trade and slavery constituted a violation of the inherent "Rights of Man" of the Africans, a post-Haitian Revolution position that extends these rights to Africans. However, even as he clearly talks about chattel slavery there is some slippage of meaning to include the proletarian 'slaves' in Britain's cotton factories. When Wedderburn subsequently demanded that "all slaves be set free, ${ }^{, 53}$ he referred not only to the chattel slaves of the Americas, but to the exploited laborers in Britain as well. Not only are the slave traders "felons," but so are the enslavers of Britain's White slaves, the manufacturers.

The same double dimension is also present when Wedderburn delivered the following rousing address ostensibly to the Jamaican planters in his Axe Laid to the Root. In a thinly veiled call to arms, he warned the planters to give in to the slaves' demands for freedom if they did not want to share the bloody fate of the planters of Saint-Domingue during the Haitian Revolution. Invoking both the Haitian revolutionaries and the Jamaican Maroons who successfully fought the British, Wedderburn thunders:

Prepare for flight, ye planters, for the fate of St. Domingo awaits you. Get ready your blood hounds, the allies which you employed against the Maroons. Recollect that fermentation will be universal. Their weapons are their bill-hooks [...] They will be victorious in their fight, slaying all before them [...] They will slay man, woman, and child, and not spare the virgin, whose interest is connected with slavery, whether black, white or tawny. $\mathrm{O}$ ye planters, you know this has been done; the cause which produced former bloodshed still remains, - of necessity similar aspects must take place. The holy alliance of Europe, cannot prevent it, they have enough to do at home, being compelled to keep a standing army in the time of peace, to enforce the civil law. My heart glows with revenge, and cannot forgive. ${ }^{54}$

In its Black Atlantic radicalness and its interconnectedness of race and class, this passage is unsurpassed in contemporary discourse. In calling for "universal" "fermentation," Wedderburn was envisioning the double transatlantic revolution that Newton and Burke had depicted as a horrific scenario: slave revolutionaries in the Americas and proto-proletarian revolutions in Europe. Wedderburn's radicalness is further reflected in his rhetoric. On the one hand, he invoked the rhetorical wrath of 52 Ibid., 81.

53 Ibid., 81.

54 Ibid., 86. 
the Old Testament, in particular its insistence on retributive justice, to lend force to his

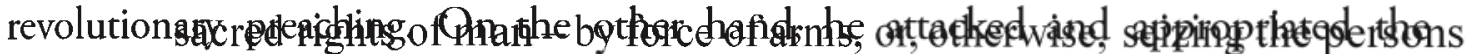
hegemonic Gothic, which had been used on numerous occasions to demonize the Black Jacobins for his own revolutionary ends, turning it into - what I have termed - the "Haitian radical Gothic." While the Gothic iconography of the slave revolt which Wedderburn referenced here was a common stereotype in pro-slavery writing in general, he might have been intertextually referring to a specific pas- sage from Bryan Edwards' Historical Survey of the French Colony in the Island of St. Domingo (1797), ${ }^{56}$ which describes the onset of the Haitian Revolution. It was quoted in most British publications on the Haitian Revolution up until at least the mid-nineteenth century and tapped into the Gothic iconography of the slave revolt with the black 'monsters' murdering the 'innocent,' the women and children:

Upwards of one hundred thousand of savage people, habituated to the barbarities of Africa, avail themselves of the silence and obscurity of the night, and fall on the peaceful and unsuspicious planters, like so many famished tygers thirsting for human blood. Revolt, conflagration, massacre, every where mark their progress; and death in all its horrors, or cruelties and outrages, compared to which immediate death is mercy, await [sic] alike the old and the young, the matron, the virgin and the helpless infant. ${ }^{57}$

Edwards' Black Jacobins were both animalized and quasi-vampiric figures: "tygers thirsting for human blood." These semi-savages, semi-animals, semivampires butchered not just those immediately responsible for slavery but their families as well. As most slave rebels agreed, the entire planter class in any colony had to be eradicated if their revolt would stand any chance of suc- cess. This slaughter of the innocent that Edwards decries, however, also consti- tuted a vital part of the pro-slavery iconography of slave revolts.

Wedderburn forcefully countered this demonization of the slave revolutionaries. His Black Jacobins were rational, smart guerrilla freedom fighters like the Haitian revolutionaries and maroons, "who will not stand to engage organised troops, like those silly Irish rebels" of 1798 and $1803^{58}$; a warning addressed as

\footnotetext{
55 See Hoermann, "A Very Hell of Horrors."

56 Bryan Edwards, An Historical Survey of the French Colony in the Island of St. Domingo (London: John Stockdale, 1797).

57 Ibid., 63.

58 Robert Wedderburn, Horrors of Slavery, 86.
} 
much to the Jamaican slaves as to the London's ultra-radicals. The slaves' killing of the 'innocent' may have been a weapon of revolutionary terror, but it also stemmed from the insight that to overcome the terror system of slavery, it might prove necessary to kill all who are implicated, irrespective of age and sex: "man, woman, and child, and not spare the virgin, whose interest is connected with slavery." Wedderburn seemed to suggest that within the slave system, any insistence on innocence becomes spurious. Furthermore, he insisted that overthrowing the horrors of slavery required revolutionary terror, as he rhetorically appropriated the hegemonic Haitian Gothic and turned it into the radical Haitian Gothic, which used tropes of terror to indict the plantation slave regime/economy and to extol the achievements of the Haitian Revolution in overthrowing it.

Moreover - and here Wedderburn was again distinctly modern - he did not see slavery as a purely racial system of exploitation and domination. Irrespec- tive of race, irrespective of whether they were "black, white or tawny," anyone implicated in this system of terror and exploitation was equally guilty. Wedderburn had his finger on the dialectics of race and class in the colonial situation, which C.L.R. James would later formulate in this decidedly Marxian chiasmus in Black Jacobins:

The race question is subsidiary to the class question in politics, and to think of imperialism in terms of race is disastrous. But to neglect the racial factor as merely incidental is an error only less grave than to make it fundamental. ${ }^{59}$

Wedderburn understood - like James - that class domination and exploitation underpinned the socio-economic systems of racial domination of slavery and/ or colonialism. This seems to be at heart of Wedderburn's appropriation of the trope of the Black Jacobin just as it would be for James. At the same time, both acknowledged the racial oppression involved in the system as well. This outlook enabled Wedderburn to agitate for a double transatlantic revolution of the European proto-proletarians and the proto-proletarian slaves in the Caribbean. Even when Wedderburn, the son of a slave, envisaged the revolutionary "Slaughter for their Liberty in England," he couched it in the rhetoric of slave revolution: "Death was as acceptable as Slavery, and if he was to die for his Lib- erty it would rouse those he left behind him to kill their masters to gain their liberty," as a spy reports him preaching. ${ }^{60}$

59 C.L.R. James, Black Jacobins, 230.

60 Robert Wedderburn, Horrors of Slavery 114. 
Although Wedderburn seemed to refer to slavery on a metaphorical level as ,

much to the Jamaican slaves as to the London's ultra-radicals. The slaves' killcapitalist socio-economic exploitation, he meant chattel slavery at the same time. Wedderburn thus developed an understanding very close to James' Black Jacobins of the double social revolution of the White sans-culottes who, having "killed their masters" were "enjoying the fruits of the earth," and the Black sans-culottes following their (misunderstood) example. In a socio-revolutionary manner, Wedderburn equally demanded that liberty must be coupled with communal land ownership, "possession of the soil" because "without that freedom is not worth possessing. ${ }^{162}$ In a certain way, Wedderburn was even more radical than James, as he insisted that the revolutionary slaves, not the French sans-culottes, must form the transatlantic vanguard, and constituted a revolutionary inspiration to - what he considered - the timid English working classes. Significantly, no- where did he even mention the French Revolution. Instead, according to a Home Office spy report, Wedderburn "said they [the slaves] fought in some instances for twenty years for 'Liberty' - and then appealed to the Britons who boasted such superior feelings and principles, whether they were ready to fight now but for a short time for their Liberties." ${ }^{163}$ Without completely conflating Black and White Jacobins, Wedderburn insisted that only their trans-racial alliance and a thus en- suing social revolution could overthrow the interrelated transatlantic systems of repression and exploitation, slavery and early capitalism. His simultaneous ap-peals to the English laborers and the Caribbean slaves were more than a rhetorical distraction from his seditious calls for insurrection in England.

Wedderburn envisioned the merger of Black and White Jacobins (or, may- be more accurately, revolutionary slaves and English proto-proletarians) in a most remarkable, poignant form in his concluding remarks to the debate on the question "has a Slave an inherent right to slay his master who refuses him his Liberty?" "When Wedderburn eventually affirms this right, he means both the "Slaves" in the British "Cotton Factories" ${ }^{55}$ and the slaves in the West In- dies. Speaking both as the son of a slave and as the ultra-radical preacher and impoverished London tailor, "Mr W. then exclaimed, well Gentlemen, I can now write home and tell the Slaves to murder their Masters as soon as they

61 Ibid., 106.

62 For a discussion of how far Wedderburn's revolutionary land plan follows the land plan of the early communist Thomas Spence and his followers, see Peter Linebaugh \& Marcus Rediker, The Many-Headed Hydra: Sailors, Slaves, Commoners, and the Hidden History of the Revolutionary Atlantic (Boston: Beacon Press, 2000), 287-326.

63 Ibid., 116.

64 Ibid., 115.

65 Ibid., 114. 
please." ${ }^{\text {"6 }}$ As a diasporic African-English-Scot, his home was neither Jamai-ca, Africa nor London, nor "Inveresk near Musselborough" where his father hailed from. ${ }^{67}$

Robert Wedderburn was a pivotal figure of the radical Black Atlantic. ${ }^{68}$ He not only employed the concept of the Black Jacobins for his revolutionary sermons, but even epitomized it in his person and his radical-revolutionary activities. Wedderburn was the paradigmatic radical Black Atlanticist Black Jacobin. As such, he also represented those hundreds of thousands of radical Black Jacobins across the Black Atlantic whose voices have not been recorded, and whose thoughts we may never know. The example of Wedderburn suggests that it was not merely the slaves of Saint-Domingue who "were closer to a modern proletariat than any group of workers in existence at that time" as it was evinced by their "rising [...], a thoroughly prepared and organised mass movement," as James argued in The Black Jacobins. ${ }^{69}$ I would argue that the Black Atlantic proletariat was at least as much avant-garde, at least ideologically, as the slaves of Saint-Domingue.

Wedderburn's intervention furcher redressed the racist and demonizing monstrous images of Black Jacobins, which Newton, Burke and others had conjured up. It thus paved the way for a positive, radical, socialist and anticolonial appropriation of the trope, which culminates in James' Black Jacobins. In James' last sustained treatment of the Black Jacobin theme in his 1967 play The Black Jacobins, he finally explicitly undertakes the reversal of the rela-tionship between White and Black Jacobins. As the subaltern Haitian soldier named after the Jacobin Jean-Paul Marat asserts:

The white slaves in France heard that the black slaves in San Domingo had killed their masters and taken over the houses and the property. They heard that we did it and they follow us. ${ }^{70}$

James' Marat in some ways constitutes a satiric Shakespearean clown figure who parodies the pretension of the revolutionary leaders, and thus James' addi- tion of subaltern Black sans-culottes for the 1967 version (in comparison to the

66 Ibid., 113.

67 Ibid., 81.

68 Alan Rice, Radical Narratives of the Black Atlantic (London; New York: Continuum, 2003), 8-13; Alan Rice, "Ghostly and Vernacular Presences in the Black Atlantic," in E.T. Bannet \& S. Manning, eds., Transatlantic Literary Studies, 1660-1830 (Cambridge University Press, 2012).

69 Ibid., 69.

70 C.L.R. James, "The Black Jacobins (1967)," in Anna Grimshaw, ed., The C.L.RJames Reader, (Oxford \& Cambridge: Blackwell, 1992), 61-111, here 74. 
1936 version) is more contradictory than critics like to acknowledge. 7 However, Marat concurs with Wedderburn who extols the Caribbean slave rebels as the transatlantic revolutionary awant-garde. For both socio-rewollutionary 'Liberty,' as freedom from economic exploitation and alienation, seem to have originated in the slaves' struggles for freedom and not with the French Jacobins. Maybe this is one of most prodmectivive aspects about the trope of the Black Jacobins: to question Eurocentric notioms about the spread of revolutionary ideas from the métropole to the colony and to acknowledge the still only partial acknowledgement that the Haitian Revolution exercised not only an enormous influence on the French Revolution but also on subsequent radically emancipatory movements across the Black and Red Atlantic.

\section{Bibliography}

Alexander, David. Richard Newton and Emglish Caricature in the 17790s. Mamecthesster. The Whitworth Art Gallery/Uminversity of Manchester Press, 11998.

Blackburn, Robin. The Overthrow offColomial Slavery 177/6-1848. London: Verso, 11988. Burke, Edmund. Select Works off Edmund Burke: Al new imprint off the Payne Edition

[F. Canavan \&E.JJ. Payne Eds.] Vol. 3. Indiamanpollis: Liberty Fund, 1999.

Burke, Edmund. Select works off Edmund Bumbe: AH New Imprint off the Payne Editition

[F. Canavan \&E.JJ. Payne Eds.] Vol. 2. Indiiammaporliss, Ind.: Liberty Fund, 11999.

Césaire, Aimẻ. Disiscounse on Colomialism. (J. Pinkham, Trams.). New York: Monthly Re- view Press, 2000.

Clavin, Matthew.J. "Race, Rebellion, and the Gotthiic: Inventing the Haitian Rexollution." Early Amemican Studities 5.1 (2007): 1-29.

Dayan, Joan. Heituti, Hilisttrmy; and the Gods. Berkeley: University of California Press, 1995. Duboiis, Laurent. "Gendered Freedom: Citoyenmes and War in the Revollutionary French Caribbean." In Gender, War and Politicas: Transentlantic Perspectives, 17755-1830 edited by Karen Hagemann Gesa Metttele and Jane Rendall. Høumdksmijlll: Macmilllans, 2010.

Edwards, Bryan. Amm Hitistorical Sumpey off the French Colony in the Islamd offSt. Domaingro. Londom: John Stockdale, 17797.

Ellis, Markman. The Hiissthony off Gothic Fiction. Edinburgh: Edinburgh University Press, 2000.

711 See Raj G. Chettyy, "The Tragicomedy of Anticolonial Overcoming: Toussitimn Lounverture and The Black Jacobins on Stage,"Callalloo: a Black South Journal offArts and Letters 37.1 (2014): 6988; Rachel Dougllas, "Making Drama out of the Revolution from Below: C.L.R. James's The BlackJacobins Play" in The Black Jacobins Reader, ed. Christian Hosbjerg and Chanlles Forsdick (Durham, NC, Dulke University Press, 2017), 278-2296. 
Fick, Carolyn E. The Making of Haiti. The Saint Domingue Revolution From Below. Knoxville: The University of Tennessee Press, 1990.

Gaspar, David Barry Geggus David Patrick. A Turbulent Time: The French Revolution and the Greater Caribbean. Bloomington: Indiana University Press, 1997.

Geggus, David Patrick, ed. The Impact of the Haitian Revolution in the Atlantic World. Columbia: University of South Carolina Press, 2000.

Gilroy, Paul. The Black Atlantic: Modernity and Double Consciousness. Cambridge, Mass.: Harvard University Press, 1993.

Høgsbjerg, Christian. C.L.R. James in Imperial Britain. Durham: Duke University Press, 2014.

Hörmann, Raphael. "Thinking the 'Unthinkable'? Representations of the Haitian Slave Revolution in the British Discourse, 1791 to 1805." In Human Bondage in the Cultural Contact Zone: Transdisciplinary Perspectives on Slavery and Its Discourses, edited by Raphael Hörmann and Gesa Mackenthun, 138-170. Münster: Waxmann, 2010.

James, C. L. R. Toussaint Louverture. The Story of the Only Successful Slave Revolt in His- tory. A Play in Three Act,s edited by Christian Høgsbjerg. Durham: Duke University Press, 2013.

James, C. L. R. The Black Jacobins: Toussaint Louverture and the San Domingo Revolu-tion, 2nd ed. London: Penguin, 2001.

Kropotkin, Peter. The Great Revolution 1789-1793. London/New York: Putnam \& Sons, 1909.

Laguerre, Michel S. Voodoo and Politics in Haiti. New York: St. Martin's Press, 1989.

Linebaugh, Peter, and Marcus Rediker. The Many-Headed Hydra. Sailors, Slaves, Commoners, and the Hidden History of the Revolutionary Atlantic. Boston: Beacon Press, 2000 .

Malchow, Howard L. Gothic Images of Race in Nineteenth-Century Britain. Stanford: University of California Press, 1996.

Maréchal, Sylvain. Manifesto of the Equals. Accessed: April 24, 2014. http://www.marxists.org/history/france/revolution/conspiracy-equals/1796/manifesto.htm

McCalman, Iain. "Antislavery and Ultra-Radicalism in Nineteenth-Century England: The Case of Robert Wedderburn." Slavery \& Abolition, 7.2 (1986): 99-117.

McCalman, Iain. Radical Underworld: Prophets, Revolutionaries, and Pornographers in London, 1795-1840. New York: Cambridge University Press, 1988.

Morris, Michael. Scotland and the Caribbean, c.1740-1833: Atlantic Archipelagos. New York: Routledge. 2015.

Nesbitt, Nick. Universal Emancipation. The Haitian Revolution and the Radical Enlightenment. Charlottesville: University of Virginia Press, 2008.

Nesbitt, Nick. Caribbean Critique: Antillean Critical Theory from Toussaint to Glissant. Liverpool: Liverpool University Press, 2013. 
Paravisimimi-Gebert, Lizabeth. "Colonial and Postcolonial Gotthice The Caribbean." In The Cambridlge Companion to Gothic Fiction, edited by J. E. Hoggle, 229-258. Cambridge: Cambridge University Press, 2000.

Paulson, Ronald. "The Severed Head: The Impact of French Revolutionary Caricatures on Britian." In French Caricature and the French Revoluation, 17898-1799 edited by Grumwald Center for the Graphic Arts, 55-65. Los Angeles: Regents of the Umiiversi- ty of California, 1988.

Reiss, Tom. The Black Count: Glomy, Revolution, Betrayal and the Real Connt off Mlonte Cristo. London: Vintage Books, 2013.

Rice, Alan J. Radical Nadrmativizes of the Black Attlamaticic. London: Continuum, 2003.

Rice, Alan J. "Ghostly and Vermacular Presences in the Black Atlantic." In Fransatlantic Litterary Studdizas, 1660-1830, edited by Eve T. Bannet and Susan Mannimg, 154-168. New York: Cambridge University Press, 2012.

Robinson, Cedric J. Black Manxissm: The Makimg off the Black Radical Tradition. London: Biblio Distribution Center, 1983.

Scott, David. Conscripts offModernity: The Traggedty offCellaniadlEnlighttemment. Durham: Duke University Press, 2005.

Singham, Shanti Marie. "Betwixt Cattle and Men: Jews, Blacks, and Women, and the Declaration of the Rights of Man." In The French Iddea off Freedom: The Old Regime and the Declaration off Rights off17789, edited by Dale Van. Kley, 114-153. Stanford: Stanford University Press, 1994.

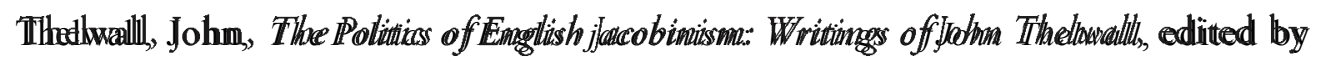
Gregory Claeys, University Park: The Pennsylvania State University Press, 11995.

Thornton, John K. "I am the Subject of the King of Congo": African Political Ideology and the Haitian Rexollution 3. Journal of World Hilistory 4.2 (1993): 181-214. Wedderburm, Robert and Iain McCalman. Hilommons off Slavery and other Writimgs. New York: Marcus Wiemer, 11991.

Wood, Marcus. Blind Mermony: Visual Representations off Slavery in England and Amemi- ca. Oxford: Oxford University Press, 2000.

Wood, Marcus. Slaverny, Emmprothyg, and Pornography. Oxford: Oxford University Press, 2002. 